\title{
Figures confirm global R\&D spending trends
}

London. Total spending on research and development (R\&D) by the world's industrialized nations fell in 1993 for the first time in many years, apparently as a combined result of a drop in military research spending by governments, and lower research budgets in private industry.

Indeed, partly as a result of the economic recession hitting the private sector, and despite calls for a greater market-oriented approach, governments' share of total national research expenditure has been increasing in several countries. In Japan, for example, it rose from 18.0 to 21.4 per cent of gross expenditure on research and development (GERD) between 1990 and 1993.

But if research expenditures are being cut back, there has been a dramatic increase in efforts to secure foreign markets for the results of research as indicated by patent applications - one of a set of research 'output' measurements that are becoming increasingly popular in science policy circles.

In particular, the overall number of 'external' patent applications, defined as patent applications filed abroad, and used as a measure of the rate at which technology is being diffused internationally, doubled between 1987 to 1992 (a period in which 'resident' applications, lodged in the countries in which inventions were made, grew by only 13 per cent).

The United States was particularly active in patenting abroad, with external applications growing from 176,763 to 413,439 , an increase of 247 per cent. Growth in Britain was slightly less, but still high, almost doubling over the five years. Both Germany and Japan, with long traditions of foreign patenting, increased such activity by 45 per cent.

All these figures are contained in the latest statistics on science and technology which have been drawn together from a variety of national and international sources by the Paris-based Organization for Economic Co-operation and Development (OECD).

The United States still heads the list of research spenders. This is true both in absolute terms (its domestic expenditure of

\begin{tabular}{lrrrr} 
Country & $\begin{array}{l}\text { R\&D spend } \\
\text { \$ billion } \\
\text { 1993 }\end{array}$ & \multicolumn{2}{c}{$\begin{array}{l}\text { Annual growth } \\
\text { in R\&D spend } \\
\text { 1990 }\end{array}$} & $\mathbf{1 9 9 3}$ \\
& & & \\
USA & 170.0 & $3.2 \%$ & $-0.5 \%$ \\
Japan & 74.8 & $8.3 \%$ & $-2.4 \%$ \\
Germany* & 37.2 & $1.5 \%$ & $-1.1 \%$ \\
France & 26.0 & $6.1 \%$ & $-0.8 \%$ \\
UK & 21.6 & $1.9 \%$ & $2.5 \%$ \\
Italy & 13.2 & $6.7 \%$ & $-1.3 \%$ \\
& & & \\
N America & 180.2 & $3.3 \%$ & $-0.4 \%$ \\
EU total & 123.1 & $3.7 \%$ & $-0.3 \%$ \\
& & & \\
OECD total & 385.5 & $4.3 \%$ & $-0.7 \%$
\end{tabular}

*figures for Germany cover western Germany in 1990, and unified Germany in 1993. per cent.
$\$ 170.0$ billion on $\mathrm{R} \& \mathrm{D}$ and 1993 represents 44 per cent of research spending by all 24 member states), and in terms of spending per head of the population (see figure right).

As far as research spending as a proportion of gross domestic product is concerned, however, it is a different story. Here, Japan still dominates the larger countries, at 2.93 per cent, even though this has fallen from 3.08 per cent in 1990 (see table below).

Furthermore, although research spending by the United States on this mea-

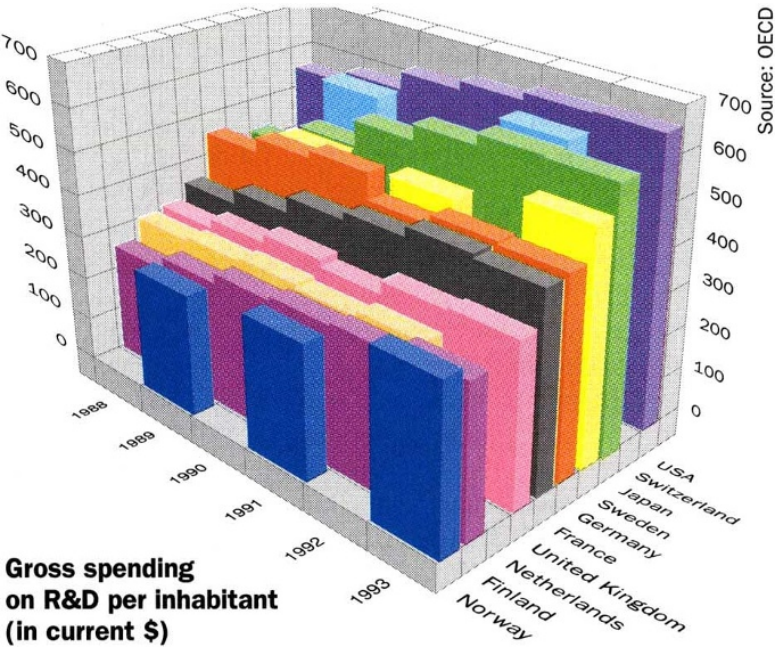
sure is still greater than most of its European competitors, it is still less than some smaller countries, such as Sweden at 3.12

Another equally significant trend to emerge from the OECD statistics is the worldwide decline that took place at the beginning of the 1990s in industrial support for research. As officials in the government of British prime minister John Major have been proudly pointing out, the United Kingdom was the only large industrialized country in which industry actually increased its support of R\&D (by an annual rate of 4.6 per cent) in 1993.

In contrast, and for a variety of different reasons (mainly linked to the economic recession), such spending was on decline in all Britain's major competitors, at rates ranging from 0.8 per cent in the United States to 6.6 per cent in Japan. This global trend was a major contributor to an overall drop of 0.7 per cent in R\&D spending as a whole by OECD member states.

In addition to compiling statistics on research spending, analysts at the OECD are now turning increasing attention to output measurements widely used to indicate the effectiveness of investment in R\&D.

Patent statistics, for example, provide a

\begin{tabular}{|c|c|c|c|}
\hline \multirow{2}{*}{\multicolumn{2}{|c|}{$\begin{array}{l}\text { National R\&D spend } \\
\text { as \% of GDP } \\
19901993\end{array}$}} & \multicolumn{2}{|c|}{$\begin{array}{l}\text { Government spend } \\
\text { as } \% \text { of } R \& D\end{array}$} \\
\hline & & 1990 & 1993 \\
\hline $2.82 \%$ & $2.72 \%$ & $43.8 \%$ & $39.0 \%$ \\
\hline $3.08 \%$ & $2.93 \%$ & $18.0 \%$ & $21.4 \%$ \\
\hline $2.76 \%$ & $2.48 \%$ & $34.1 \%$ & $37.1 \%$ \\
\hline $2.41 \%$ & $2.41 \%$ & $48.3 \%$ & $\mathrm{n} / \mathrm{a}$ \\
\hline $2.23 \%$ & $2.19 \%$ & $34.8 \%$ & $32.3 \%$ \\
\hline $1.30 \%$ & $1.30 \%$ & $51.5 \%$ & $45.9 \%$ \\
\hline $2.70 \%$ & $2.44 \%$ & $43.8 \%$ & $39.6 \%$ \\
\hline $2.00 \%$ & $1.96 \%$ & $40.6 \%$ & $\mathrm{n} / \mathrm{a}$ \\
\hline $2.39 \%$ & $2.24 \%$ & $37.7 \%$ & $36.2 \%$ \\
\hline
\end{tabular}

more optimistic picture than research budgets alone. Overall, the number of patent applications in the 24 states rose by 47 per cent between 1987 and 1993,

However, particularly large increases in smaller countries such as Denmark (354 per cent) and Greece ( 280 per cent), reflect the growing interest of foreign companies in the markets of such countries as much as any growth in indigenous patentable research.

A further indication of this trend is given by the fact that whereas the 'dependency ratio' - the ratio of non-resident to resident patent applications - increased only from 0.95 to 1.01 over these five years in the United States, it grew from 2.28 to 4.00 in the member states of the European Union over the same period.

Even so, the United States did relatively badly in terms of 'inventiveness coefficient', the number of resident patent applications per 10,000 population. Top of the list came Japan, a highly patent-conscious society, with a ratio of 27.2.

Second was Switzerland, with a ratio of 4.8, and third - despite its low spending on R\&D - was Australia, with 4.5. By contrast, the United States came seventh, below Germany, Finland and Sweden, and just in front of the United Kingdom.

\begin{tabular}{|c|c|c|c|}
\hline \multirow{2}{*}{\multicolumn{2}{|c|}{$\begin{array}{l}\text { Civilian spend as } \\
\% \text { of govt R\&D } \\
1990\end{array}$}} & \multicolumn{2}{|c|}{$\begin{array}{l}\text { Rate of increase } \\
\text { in industry R\&D }\end{array}$} \\
\hline & & 1990 & 1993 \\
\hline $37.4 \%$ & $41.0 \%$ & $6.6 \%$ & $-0.8 \%$ \\
\hline $94.6 \%$ & $93.9 \%$ & $10.0 \%$ & $-6.6 \%$ \\
\hline $86.5 \%$ & $91.5 \%$ & $1.2 \%$ & $-2.4 \%$ \\
\hline $60.0 \%$ & $66.5 \%$ & $5.1 \%$ & $\mathrm{n} / \mathrm{a}$ \\
\hline $57.5 \%$ & $54.9 \%$ & $-0.3 \%$ & $4.6 \%$ \\
\hline $93.9 \%$ & $93.5 \%$ & $0.6 \%$ & $-4.4 \%$ \\
\hline 39.9 & $44.6 \%$ & $6.5 \%$ & $-1.0 \%$ \\
\hline $77.2 \%$ & $81.1 \%$ & $2.1 \%$ & $n / a$ \\
\hline $60.2 \%$ & $64.1 \%$ & $5.8 \%$ & $-2.2 \%$ \\
\hline
\end{tabular}

